\title{
Cinnamon species: In vivo Anti-Oxidant Activity of Ethanolic Extracts of Cinnamon zeylanicum and Cinnamon cassicae Barks
}

\author{
Balasubramanian Prasanna ${ }^{1, *}$, Arumugam Vijaya Anand ${ }^{2}$
}

\section{Balasubramanian Prasanna ${ }^{1, *}$, Arumugam Vijaya Anand ${ }^{2}$}

'Department of BioChemistry, Manonmaniam Sundaranar University, Tirunelveli, Tamil Nadu, INDIA. 2Department of Human Genetics and Molecular Biology, Bharathiar University, Coimbatore-641 046, Tamil Nadu, INDIA.

Correspondence

Mr. Balasubramanian Prasanna

Research Scholar, Department of Biochemistry, Manonmaniam Sundaranar University, Tirunelveli, Tamil Nadu, INDIA

Phone no : +9198425 25830

E-mail: avamiet@yahoo.co.in

prasanna@morpheusivf.com

History

- Submission Date: 20-08-2018;

- Review completed: 06-11-2018;

- Accepted Date: 23-11-2018.

DOI : 10.5530/pj.2019.11.38

Article Available online

http://www.phcogj.com/v11/i2

\section{Copyright}

(C) 2019 Phcog.Net. This is an openaccess article distributed under the terms of the Creative Commons Attribution 4.0 International license.

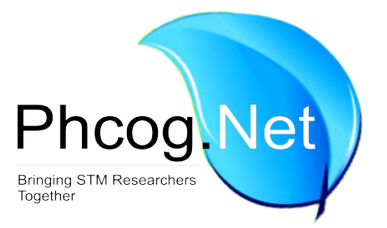

\begin{abstract}
Background: The diabetic population is increasing highly in the worldwide due to the poor control of diabetes and environmental conditions. It disturbs the carbohydrate, protein and lipid metabolism. The natural medicines obtained from the plant source may be the effective treatment of diabetes. Objective: The aim of the present study is to investigate the antioxidant activities of the ethanolic bark extract of Cinnamon zeylanicum and Cinnamon cassiacae. in Streptozotocin (STZ) induced oxidative stress in rats. Methods: Oxidative stress is induced with a single dose of STZ $60 \mathrm{mg} / \mathrm{kg} \mathrm{b.w.} \mathrm{and} \mathrm{then} \mathrm{the} \mathrm{animals} \mathrm{are} \mathrm{treated} \mathrm{with} \mathrm{a} \mathrm{dose} \mathrm{of}$ various concentrations of ethanolic bark extract of Cinnamon zeylanicum and Cinnamon cassiacae $(200 \mathrm{mg} / \mathrm{kg} \mathrm{b.w,} 400 \mathrm{mg} / \mathrm{kg} \mathrm{b.w}$, and $600 \mathrm{mg} / \mathrm{kg} \mathrm{b.w})$ for 45 days. After the treatment lipid peroxides (LPO), Reduce Glutathione (GSH), Glutathione Peroxidase (GPx), Superoxide Dismutase (SOD) and Catalase (CAT) levels are determined. Glibenclamide is used as a standard drug (3 mg/kg b.w.). Results: The present study exposed that the administration of ethanolic bark extract of Cinnamon zeylanicum and Cinnamon cassiacae showed a significant decrease in LPO levels. The treatment also finds that the significant increase in GSH, GPx, SOD and CAT levels in the liver, when compared with diabetic control rats. Conclusion: The results proved that the ethanolic bark extract of Cinnamon zeylanicum and Cinnamon cassiacae treated group may effectively regulate the antioxidant status in STZ induced diabetic treated groups.

Key words: Diabetes mellitus, Cinnamon zeylanicum, Cinnamon cassicae, Streptozotocin,
\end{abstract} Anti-oxidant activity

\section{INTRODUCTION}

Diabetes mellitus is a common metabolic disorder associated with the imbalance in glucose level in the blood leading to hyperglycemia and a series of secondary complications due to the low level of insulin. In our body, it needs insulin to the cells to utilizes the excess blood glucose. The major effects of insulin on the biomolecular metabolism on ion flux are begins by the attachment of the insulin molecule to a specific insulin receptors on the cell surface. The insulin resistance happens in the cell surface. The insulin resistance happens in cell surface, where glucose is not transported to the cell for oxidation this leads to the increasing of glucose level in the blood. The insulin resistance symptoms are decreased glycogen synthesis in muscle, hexokinase activity and uptake of glucose. Indian Council of Medical Research (ICMR) predicts in India, nearly 40.9 million peoples are affected by diabetes, which is increased upto 69.9 million in the year of 2025. ICMR indicates $2.1 \%$ are from urban population and $1.5 \%$ are from the rural population are affected by diabetes. ${ }^{1}$ Various anti-diabetic drugs are available such as sulphonylurea, biguanides, meglitinide analogues and thiazolidine diones. This type of treatment is very expensive as well as it causes the various side-effects such as abdominal pain, diarrhea, respiratory infections, anemia etc. Due to this the researchers are try to find the new alternate treatment for diabetes without any side-effects and low cost. $^{2}$

Now-a-days the term alternative medicine became common in western culture the idea is focusing the uses of plants for medicinal purpose. Medicinal plants are used as a raw material for extraction of secondary metabolites, which is used in the synthesis of new drugs and this is used for various diseases. Cinnamon zeylanicum (C. zeylanicum) and Cinnamon cassicae (C. cassicae) are the important plants in the Lauraceae family. Cinnamon is one of the most vital spices used by the peoples in all over the world. The various parts of the cinnamon consists the various phytoconstituents like cinnamaldehyde, eugenol, caryophyllene and copane. ${ }^{3}$ In recent studies proves that the cinnamon is have anti-microbial activity, ${ }^{4}$ anti-inflammatory activity, ${ }^{5}$ anti-fungal activity ${ }^{6}$ and anti-oxidant activity. ${ }^{7}$ Hence, the present study aims to find the anti-oxidant activity of ethanolic extracts of C. zeylanicum and C. cassicae barks in an in vivo models. 


\section{MATERIALS AND METHODS}

\section{Plant material and extraction}

The fresh barks of C. zeylanicum and bark of C. cassicae are collected locally and authenticated by Botanist at Rapinat Herbarium, St. Joseph College, Trichy, Tamil Nadu, India. The extraction of C. zeylanicum and C. cassicae barks are done by a hot percolation method with Soxhlet apparatus. Ethanol is used as a solvent. About $100 \mathrm{gm}$ of the powder of the plant materials is extracted with $600 \mathrm{ml}$ of ethanol. The extract is concentrated to dryness under controlled temperature of $40-50^{\circ} \mathrm{C}$.

\section{Animals}

Male albino rats of 6-8 weeks age, weighing $150-180 \mathrm{~g}$ is used. The animals are kept in clean plastic cages. The rats are fed with standard pellet diet and water. This study is carried out in the animal house of Srimad Andavan Arts and Science College, Trichy (CPCSEA approval No- 790/03/ac/ CPCSEA) and this study is approved by the Institutional Ethical Committee. The animals are divided into nine groups with six rats each.

Group I: Normal rats (saline $2 \mathrm{ml} / \mathrm{kg}$ body weight).

Group II: Diabetic control rats (STZ induced as $60 \mathrm{mg} / \mathrm{kg} \mathrm{b.w).}$

Group III: Normal rats are fed with C. zeylanicum extract for 45 days (600 mg/kg b.w)

Group IV: Normal rats are fed with C. cassicae extract for 45 days (600 $\mathrm{mg} / \mathrm{kg}$ b.w)

Group V: Diabetic induced animals are fed with C. zeylanicum extract for 45 days ( $400 \mathrm{mg} / \mathrm{kg} \mathrm{b.w)}$.

Group VI: Diabetic induced animals are fed with C. zeylanicum extract for 45 days $(600 \mathrm{mg} / \mathrm{kg} \mathrm{b.w})$.

Group VII: Diabetic induced animals are fed with C. cassicae extract for 45 days (400 mg/kg b.w).

Group VIII: Diabetic induced animals are fed with C. cassicae extract for 45 days $(600 \mathrm{mg} / \mathrm{kg} \mathrm{b.w})$.

Group IX: Diabetic induced animals are fed with standard drug glibenclamide (3 mg/kg b.w).

\section{Biochemical Analysis}

The anti-oxidant status is assessed in the liver of the experimental rats. A known weight of the tissue was homogenized in $0.1 \mathrm{M}$ ice cold tris$\mathrm{HCl}$ buffer ( $\mathrm{pH} 7.5$ ) to give a 10\% homogenate and used as the source of antioxidants. The levels of Lipid Peroxides (LPO), ${ }^{8}$ Reduce Glutathione (GSH), ${ }^{9}$ Glutathione Peroxidase (GPx) ${ }^{10}$ Superoxide Dismutase (SOD), ${ }^{11}$ and Catalase (CAT), ${ }^{12}$ Blood glucose,${ }^{13}$ urea $^{14}$ and creatinine ${ }^{15}$ are estimated at the end of the study ( $45^{\text {th }}$ day).

\section{Statistical analysis}

Statistical analysis is carried out by using one-way ANOVA as in Standard Statistical Software Package of Social Science (SPSS) version 14.0. $P$ values $<0.05$ are considered as level of significance.

\section{RESULTS AND DISCUSSION}

Table 1 shows the level of LPO, GSH, GPx, SOD and CAT in the normal and plant extract treated rats. The level of LPO is increased in the group-II, as compared to the group-I. After the treatment of C. zeylanicum and C. cassicae the levels were return to the normal. These levels were compared to the group-I and group-IX (standard drug treated rats).

The level of GSH, GPx, SOD and CAT is reduced in the group-II rats, compared to the group-I rats. The levels of enzymes are increased in the plant extract treated rats. The levels were compared to the standard drug
Table 1: The levels of LPO, GSH, GPx, SOD and CAT levels in the control, toxin treated plant extract and standard drug treated rats.

\begin{tabular}{cccccc}
\hline $\begin{array}{c}\text { Treatment } \\
\text { groups }\end{array}$ & $\begin{array}{c}\text { LPO } \\
(\mathrm{n} \mathrm{mol} / \mathrm{g})\end{array}$ & $\begin{array}{c}\text { GSH } \\
(\mathrm{mg} / \mathrm{g})\end{array}$ & $\begin{array}{c}\text { GPx }(\mu \mathrm{mol} / \\
\mathrm{min} / \mathrm{mg})\end{array}$ & $\begin{array}{c}\text { SOD } \\
(\mu \mathrm{mol} / \mathrm{min} / \\
\mathrm{mg})\end{array}$ & $\begin{array}{c}\text { CAT } \\
(\mu \mathrm{mol} / \mathrm{min} / \\
\mathrm{mg})\end{array}$ \\
\hline Group I & $1.96 \pm 0.21$ & $19.62 \pm 0.36$ & $25.32 \pm 0.47$ & $12.63 \pm 0.27$ & $27.38 \pm 0.98$ \\
Group II & $4.78 \pm 0.72$ & $6.32 \pm 0.13$ & $12.61 \pm 0.91$ & $4.62 \pm 0.46$ & $13.62 \pm 0.72$ \\
Group III & $1.95 \pm 0.34$ & $19.59 \pm 0.71$ & $25.27 \pm 0.52$ & $12.72 \pm 0.17$ & $27.67 \pm 0.18$ \\
Group IV & $1.92 \pm 0.51$ & $19.03 \pm 0.52$ & $25.41 \pm 0.61$ & $12.83 \pm 0.71$ & $27.72 \pm 0.23$ \\
Group V & $3.94 \pm 0.12$ & $13.43 \pm 0.54$ & $17.14 \pm 0.76$ & $7.13 \pm 0.71$ & $17.62 \pm 0.91$ \\
Group VI & $2.31 \pm 0.62$ & $17.12 \pm 0.34$ & $22.62 \pm 0.17$ & $11.12 \pm 0.53$ & $25.16 \pm 0.53$ \\
Group VII & $3.86 \pm 0.74$ & $14.12 \pm 0.46$ & $18.62 \pm 0.42$ & $7.46 \pm 0.32$ & $17.78 \pm 0.72$ \\
Group VIII & $2.20 \pm 0.81$ & $17.98 \pm 0.76$ & $22.67 \pm 0.28$ & $11.27 \pm 0.62$ & $25.72 \pm 0.86$ \\
Group IX & $2.07 \pm 0.53$ & $18.42 \pm 0.96$ & $25.44 \pm 0.51$ & $11.96 \pm 0.49$ & $26.32 \pm 0.62$ \\
\hline
\end{tabular}

treated rats. The plant extract alone treated groups have the similar values to the group-I rats.

Prolonged elevation of glucose in blood induces the free radicals production and it alters the cellular functions. The damaged cell membrane induces the lipid peroxidation. ${ }^{16}$ This lipid peroxides are attacks the membranes and damages the protein and DNA and it leads the various diabetic secondary complications. ${ }^{17}$ The generation of free radicals is directly proportional to the degree of tissue damage. In our body naturally have an anti-oxidant defense mechanism, but in tissue damages the level of free radicals are increased. In the present study, the lipid peroxide level is elevated in the toxin STZ induced diabetic rats and the levels are return back to the normal after the treatment of ethanolic extract of barks of C. zeylanicum and C. cassicae. These values are similar to the standard drug treated group.

GSH is an important free radical scavenger in an intracellular region. It mainly maintains the anti-oxidant status in plasma as well as act as a important cofactor for several enzymes. In the present study, the GSH level is reduced in the diabetic control group. The previous study the high concentration of glucose decreases the GSH levels in muscle cells ${ }^{18}$ and mesangial cells. ${ }^{19} \mathrm{~A}$ decreased GSH content in the cells reduces the defense activity of the body against the oxidative stress in the diabetic conditions. ${ }^{17}$

GPx is an enzyme which is mainly involved in the removal of hydrogen peroxide. ${ }^{20}$ It also destroys the lipid peroxides and it provides the antioxidant defense of an organism. In diabetic conditions the level of GPx is reduced and this favours the accumulation of lipid peroxides (LPO). This LPO increases the oxidative stress in diabetic rats. ${ }^{21}$ In the present study, the level of GPx is reduced in diabetic rats, after the treatment of C. zeylanicum and C. cassicae which increase the GPx concentration. The increasing GPx is inversely proportional to the concentration of LPO.

SOD is a vital anti-oxidant enzyme. Mainly it involves the elimination of superoxide anion, it changes the hydrogen peroxide from superoxide anion due to this the toxic effect is retards in our body. If this enzyme is lowered it induces the oxidative stress in diabetic models. ${ }^{21}$ In the present study, the SOD levels are diminished and the levels are back to the normal in the treatment of C. zeylanicum and C. cassicae. The levels are similar to the standard drug treated groups.

CAT is an enzyme, present in the animal tissues. It mainly breaks the hydrogen peroxide molecule. This prevention reduces the tissue damage from the reactive hydroxyl radicals. ${ }^{22}$ The enzyme CAT activity is diminised in the diabetic rats. After the treatment of C. zeylanicum and C. cassicae the levels are return back to the normal and these values which is similar to the standard drug treated groups. 


\section{CONCLUSION}

The results proved that the ethanolic extract of both C. zeylanicum and C. cassicae are regulate the anti-oxidant status in the diabetic rats. This anti-oxidant property may reduce the various secondary complications in our body. Further studies are warranted for the compound identification, isolation for the responsible of the pharmacological properties of the both barks of C. zeylanicum and the C. cassicae.

\section{ACKNOWLEDGEMENT}

The authors are grateful to Dr. Sridharan, Srimath Andavan College of Arts and Science, Trichy, for his guidance and encouragement.

\section{CONFLICT OF INTEREST}

The authors declare no conflict of interest.

\section{ABBREVIATIONS}

C. zeyalnicum: Cinnamon zeylanicum; C. cassicae: Cinnamon cassicae; CAT: Catalase; GPx: Glutathione peroxidase; GSH: Reduce glutathione; LPO: Lipid peroxides; SOD: Superoxide dismutase; SPSS: Standard Statistical Software Package of Social Science; STZ: Streptozotocin.

\section{Highlights of the paper}

This article highlights the recent scientific support for the anti-oxidant potential of C. zeylanicum and C. cassicae in diabetic induced animal models.

\section{REFERENCES}

1. Mohan V, Sundeep S, Deepa R, Shah B, Varghese C. Epidemology of type 2 diabetes. Indian Scenario. Indian J Med Res. 2007;125(3):217-30.

2. Timothy M, Simon G, Jacob IG, Max B, David W. Determinants of severe hypoglycemia complicating type 2 diabetes: The fremantle diabetes study. J Clin Endocrino Metab. 2010;95(5):2240-7.

3. Vangalapati M, Sree S, Surya P, Avanigadada S. A review on pharmacological activities and clinical effects of Cinnamon species. Research Journal of Pharmaceutical, Biological and Chemical Sciences. 2012;(1):653-63.
4. Chang ST, Chen PF, Chang SC. Antibacterial activity of leaf essential oils and their constituents from Cinnamomum osmophloeum. J Ethnopharmacol. 2001;77(1):123-7.

5. Chao LK, Hua KF, Hsu HY, Cheng SS, Liu JY, Chang ST. Study on the anti-inflammatory activity of essential oil from leaves of Cinnamomum osmophloeum. J Agric Food Chem. 2005;53(18):7274-8.

6. Sheng-Yang W, Pin-Fun C, Shang-Tzen C. Anti-fungal activities of essential oils from indigenous Cinnamon leaves. 2005;96(7):813-8.

7. Shobana S, Akhilender NK. Anti-oxidant activity of selected Indian spices. Prostaglandins Leukotrienes and Essential Fatty Acids. 2000;62(2):107-10.

8. Gohel A, Mc Carthy MB, Gronowic Z. Estrogen prevents glucocorticoid induced apoptosis in oesteoblasts in vivo and in vitro. Endocrinology. 1999;140(11):5339-47.

9. Carlberg MB. Biochemical studies on hypoglyceamic effect of blood glutathione. J Biol Chem. 1975;250(14):5475-80.

10. Rotruck JT, Pope AL, Ganther HE. Selenium: Biochemical role as a component of Glutathione peroxidase, purification and assay. Science. 1973;179(4073):588-90

11. Misra HP, Fridovich I. The role of superoxide anion in the autooxidation of epinephrine and a simple assay for SOD. J Biol Chem. 1979;247(10):3170-5.

12. Sinha AK. Colorimetric assay of catalase. Anal Biochemal. 1972;47(2):389-94

13. Sasaki T, Mutsui S. Effect of acetic acid concentration on the colour reaction in the O-toludine-boric acid method for blood glucose estimation. Rinshodagaker. $1972 ; 1(3): 346-53$

14. Tomas L. Clinical laboratory diagnostics (1 $1^{\text {st }}$ edn.). Frankfurt: TH-books Verlagsgesellschaft. 1998;208-14.

15. Tomas L. Clinical laboratory diagnostics ( $1^{\text {st }}$ edn.). Frankfurt: TH-books Verlagsgesellschaft; 1998;366-74.

16. Giugliano D, Ceriello A, Paolisso G. Oxidative stress and diabetic vascular level and the P.E. fraction showed a moderate increase in GSH complications. Diabetes Care. 1996;19(1):257-67.

17. Gopalakrishnan G, Dhanapal CK. Evaluation of in vivo antioxidant activity of ethanolic extract of Coleus vettiveroides Jacob in streptozotocin induced oxidative stress in rats. Int J Pharm Pharm Sci. 2013:6(1):590-2.

18. Sharpe PC, Yue KK, Catherwood MA, Mcmaster D, Trimble ER. The effects of glucose-induced oxidative stress on growth and extracellular matrix gene expression of vascular smooth muscle cells. Diabetologia. 1998;41(10):1210-9.

19. Catherwood MA, Powell LA, Anderson P, Mcmaster D, Sharpe PC, Trimble ER. Glucose-induced oxidative stress in mesangial cells. Kidney Int. 2002;61(2): 599-608.

20. Chen S, Schopfer P. Hydroxyl radical production in physiological reaction. A novel function of peroxidise. Eur J Biochem. 1999;260(3):726-35.

21. Kaleem M, Asif M, Ahmed OU, Bano N. Antidiabetic and antioxidant activity of Annona squamosa extract in streptozotocin induced diabetic rats. Singapore Med. 2006;47(8):670-5

22. Chance B, Greenstein DS. The mechanism of catalase actions-steady state analysis. Arch Biochem Biophys. 1992;37(2):301-39.

\section{SUMMARY}

- The rats are grouped into nine. The STZ is used to induce the diabetes in rats. Then the diabetic rats are treated with the barks of $C$. zeylanicum and $C$. cassicae ethanolic extract. The ethanolic extract of both $C$. zeylanicum and $C$. cas sicae are regulate the anti-oxidant status in the diabetic rats.

Cite this article: Prasanna B, Anand AV. Cinnamon species: In vivo Anti-Oxidant Activity of Ethanolic Extracts of Cinnamon zeylanicum and Cinnamon cassicae Barks. Pharmacog J. 2019;11(2):245-7. 